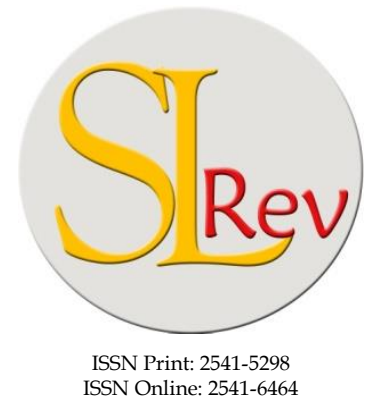

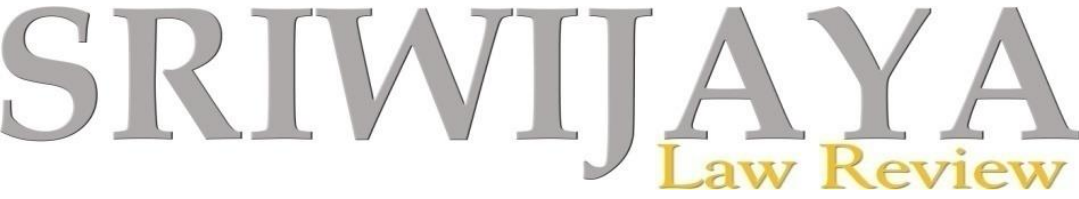

Editorial Office: Faculty of Law, Sriwijaya University, Jalan Srijaya Negara, Palembang, South Sumatra 30139, Indonesia Phone: +62711-580063Fax: +62711-581179

E-mail: sriwijayalawreview@unsri.ac.id| sriwijayalawreview@gmail.com Website: http://journal.fh.unsri.ac.id/index.php/sriwijayalawreview

\title{
The Political Law on Coal Mining in the Fulfilment of People's Welfare in Indonesia
}

\author{
Irsan $^{*}$ and Meria Utama ${ }^{* *}$
}

\begin{abstract}
The main issue of this research is how the political law on coal mining to manifest the people's prosperity in Indonesia based on the sustainable development principle. Using normative research with an interdisciplinary research approach such as law and sociological approach, it gains some results: firstly, in the legal issue, Indonesian government should comply with the Article 33 of the 1945 Constitution, as an economic system aimed in realizing people's sovereignty in the economic field. Secondly, some regulations related to coal mining still have some loopholes. As a result, it needs evaluation in the field of legal structure to enforce the rule of law based on the communities' existing values as the reflection of Pancasila and the 1945 Constitution. Thirdly, the control of the state in the coal utilization and a new balancing in national policy management based on the sustainable development are necessary where the objectives of coal exploitations in mining are not only to pursue economic gain but also to have equal responsibilities to the social and the environment.
\end{abstract}

Keywords: Article 33 of the 1945 Constitution; Coal Mining; Coal Policy; People Welfare;

Principles of Sustainable Development.

\section{ARTICLE HISTORY:}

\section{DOI: 10.28946/slrev.Vol3.Iss1.202.pp11-25}

Received: Oct 03, 2018;

Reviewed: Jan 10, 2019;

Accepted: Jan 21, 2019;

Published: Jan 31, 2019.

* Faculty of Law, Padjajaran University, E-mail: irsanrusmawimuchtar@yahoo.com

** Faculty of Law, Padjajaran University, E-mail: meriautama@yahoo.co.id

\section{INTRODUCTION}

The State of Indonesia is a unitary state which has the form of Republic. ${ }^{1}$ As a state of law, the government power in this country is based on a constitutional. The supremacy of law must include three basic ideas

1 Article 1 (paragraph 1 and 3) the 1945 Constitution. namely justice, benefit, and certainty. So that within the State of law, the "sense of people justice" should not ignore. In the Constitution, the use of the earth, water and natural resources contained therein, shall be arranged that the public may utilize or obtain the greatest results for the welfare of the people. The Constitution inexplicitly mention of what kind of mining activities that can result the proper prosperity and welfare.

The implementation of Article 33 on Indonesian Constitution, haven't accommodated by the government policy and other lower regulation. Therefore, in some province of Indonesia, the problem of mining continues with various complexities. For Instant there are same problems in South Sumatera which indicate in Table 1 , and 
problems in East Kalimantan will be elaborate in Table 2.

Table 1: South Sumatera Conditions

\begin{tabular}{|c|c|c|}
\hline No. & Causes & Impact \\
\hline 1 & $\begin{array}{l}\text { The motto that } \\
\text { "South Sumatera } \\
\text { is the food and } \\
\text { energy" }\end{array}$ & $\begin{array}{l}\text { It means that the } \\
\text { government sup- } \\
\text { ports exploitation } \\
\text { and exploration of } \\
\text { coal mining on a } \\
\text { large scale. As a re- } \\
\text { sult, the area of } \\
\text { SUMSEL which ap- } \\
\text { proximately from to- } \\
\text { tally } 8.7 \text { million hec- } \\
\text { tares allocated for } \\
\text { mining and planta- } \\
\text { tions almost } 5 \text { mil- } \\
\text { lion hectares. }{ }^{2}\end{array}$ \\
\hline 2 & Coal Mining & $\begin{array}{l}\text { Coal transportation } \\
\text { that disrupted public } \\
\text { roads. It also caused } \\
\text { road damage, con- } \\
\text { gestion, and many } \\
\text { accidents. }\end{array}$ \\
\hline 3 & $\begin{array}{l}\text { The Result of } \\
\text { Coordination and } \\
\text { Supervision of } \\
\text { Indonesian' Cor- } \\
\text { ruption Eradica- } \\
\text { tion Commission } \\
\text { (KPK) }\end{array}$ & $\begin{array}{l}\text { There are } 31 \text { compa- } \\
\text { nies that have no tax } \\
\text { registration number, } \\
170 \text { companies hasn't } \\
\text { clean and clear such } \\
\text { as having the li- } \\
\text { cense in a conserva- } \\
\text { tion area for about } \\
9,300 \text { hectares. As } \\
\text { the result of that in- } \\
\text { vestigation, and sug- } \\
\text { gestion from } \\
\text { WALHI of South } \\
\text { Sumatera and others } \\
\text { organisations The } \\
\text { Government of }\end{array}$ \\
\hline
\end{tabular}

2 Wijaya, Taufik and Rahmad, Rahmadi. (2014) Batubara, Emas Hitam yang Sarat Permasalahan. [Online] Available at: http://www.mongabay.co.id/2014/12/31/batubara-emas-hitam-yang-saratpermasalahan/ (retrieved: November 14, 2018)

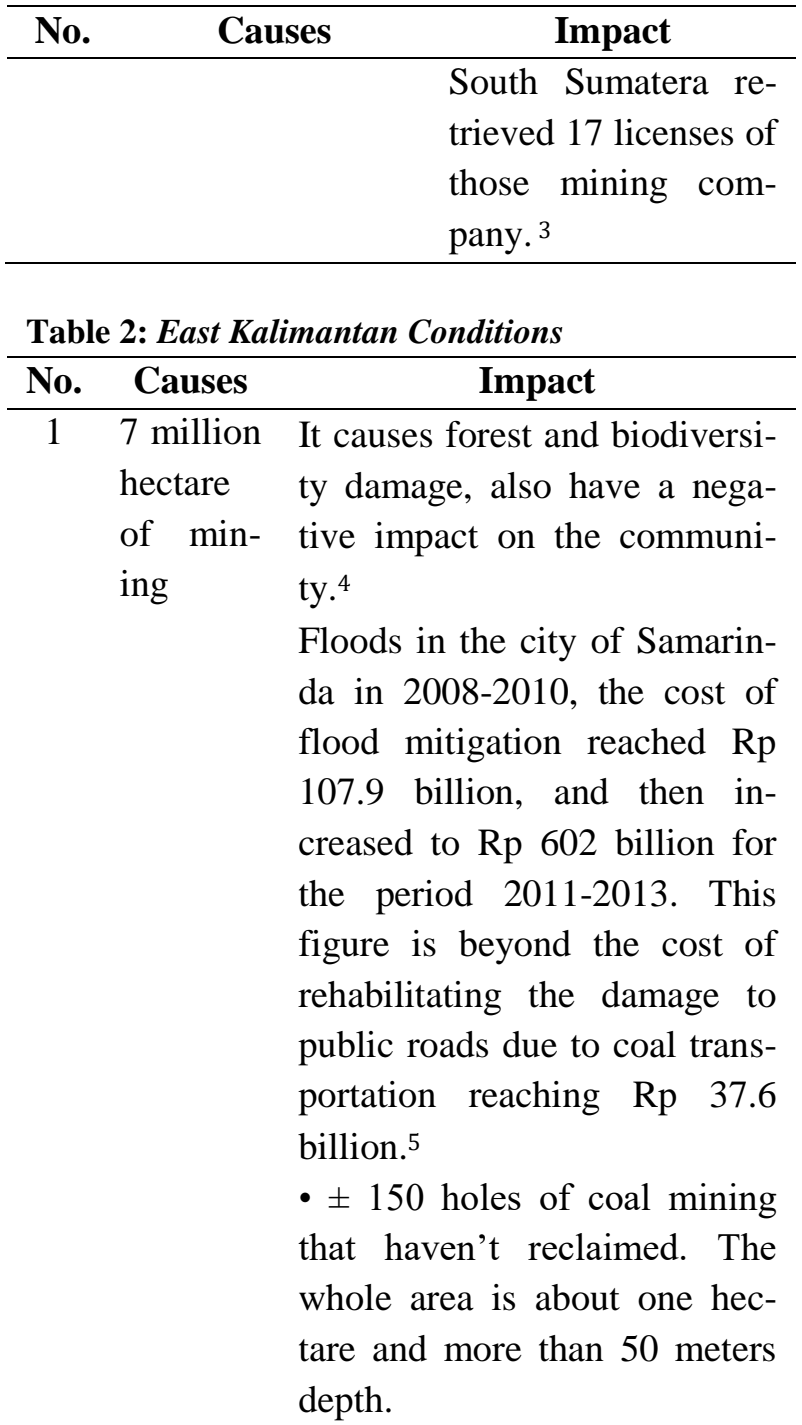

Other five problems i.e. the implementation of reporting obligations regularly, the implementation of the duty to reclamation after mining, enacted the government regulation of coal and mining law, the development of data and information system, the implementation of supervision and optimization of state revenue.

On the other hand, one important investigation of KPK that there is no standard map of mining which used by government, BPN and Ministry of Energy and mining

Wijaya, Taufik and Rahmad, Rahmadi. Note 2. Wijaya, Taufik and Rahmad, Rahmadi. Note 2. Wijaya, Taufik and Rahmad, Rahmadi. Note 2. 
sources. This standard map is also a problem that is very detrimental to society, boundary issues, and land grabbing that is the most touching issue to the community. In all conflicts, mostly people's positions are always on the weaker parties. One of the reasons is the alignment of the state apparatus, both central government and regional, police and military to the corporation itself.

In realizing sustainable development in coal minerals mining, it has 3 (three) aspects namely economy benefit, social and environmental that must be run in a balanced way. Mining activities not only pursue economic gain, but also have equal responsibilities to the social and the environment. It is hope that the prosperity of the people can be achieved.

On the other hand, the Neoliberalism is already running and entering in various forms in Indonesia. Prosperity of the people can be interpreted as in the concept of $\mathrm{Ne}$ oliberalism; the State provides an opportunity for individuals or private parties in order to have the greatest opportunity in utilizing the mining business. Even in the divestment of shares of mining companies can be purchased by any individual, so the profits of the mining company cannot be enjoyed by the "people" as intended in Article 33 paragraph (3) of the 1945 Constitution. People are not individuals or groups. According to Giers ${ }^{6}$ implementation of economic policy in neoliberalism has a goal to:

1. Development of individual freedom to compete freely in the market.

2. Private ownership of factors of production is recognized.

6 Revrisond Baswir. Bahaya Neoliberalisme, Yogyakarta: Pustaka Pelajar, 2009, p2.
3. Establishment of market price conducted by the State through the issuance of law.

According to Big Indonesian Dictionary, prosperous is [1] a lot of results; [2] many population and prosperous; [3] sufficiency, no shortage. ${ }^{7}$ The condition of prosperity above means that the community lives in a state of affluence, not otherwise troubled by the conditions of utilization of the mine. Until now, Indonesia is in a condition that has not been able to get the benefits of the mining. Some problems which arise among others; environmental damage, human rights violations and social justice, inequality and poverty (Welfare and equality), as well as Labour exploitation. ${ }^{8}$ Though Indonesia is a country based on the Law and welfare state which is responsible for ensuring fairness and minimum welfare standards for every citizen. And the State has the authority to regulate, maintain and distribute prosperity as stipulated in Article 33 paragraph (3) and (4) of the 1945 Constitution.

The fundamental problem then arises is, what coal mining policy in order to realize sustainable development as an effort to improve people's welfare. Then, the next question is that whether the purpose of the utilization of the mine has been achieved currently and how is the benchmark that it has been achieved. Lest precisely now, the regulations related to mining have not reached the desired direction or goal in accordance with the preamble of the 1945 Constitution and Article 33 paragraph (3) and (4) of the

Kamus Besar Bahasa Indonesia (KBBI). (2018). [Online] Available at: http://kbbi.web.id/makmur [retrieved: 28 March 2018].

8 Dody Prayogo, 2008, "Corporate Social Responsibility, Social Justice dan Distributive welfare in Industri tambang dan migas di Indonesia," Jurnal Galang, 3 (3). 
1945 Constitution. Base on above problems, this article will discuss First, How the condition of coal mining in Indonesia, Second, how Indonesia coal mining regulations, able to realize sustainable development as an effort to improve people's welfare and Third how about the legal politics of coal mining in realizing the sustainable development as an effort of improving people prosperity according to Indonesian legal system.

\section{RESEARCH METHOD}

The method to analyse and elaborate on the above problems in this article is using interdisciplinary legal approach i.e. a comparative law and sociological approach. It compares the data from some provinces in Indonesia as well as other countries. Then for its related to the national welfare, therefore the problems are analysed by using sociological approach. The type of this research is descriptive analytic, which elaborate systematically based on data. It will elaborate the problems by using Sustainable Principles and related to the legal system in Indonesia. The data is using secondary data such as regulations as primary data, and other supported documents. Those data will analyse qualitative juridical using legal interpretation and legal construction methods.

\section{ANALYSIS AND DISCUSSION}

\section{Coal Mining in Indonesia}

Coal is one of the important energy commodities in Indonesia. Its Mining has been done since the Dutch colonial period. The history of coal mining can be divided based on the island's mining location. Coal mining by the Netherlands was first conducted on the island of Borneo and Sumatra Island which is until now become the main produce of coal in Indonesia. ${ }^{9}$ The distribution of coal in Indonesia is spread evenly on the islands of Sumatera and Kalimantan as indicate on figure 1. Small coal reserves are found on the islands of, Java, Kalimantan, Sulawesi and Papua. Three regions with the largest coal reserves are South Sumatra, South Kalimantan and East Kalimantan. Indonesia's coal industry is divided by a few large producers and many small-scale actors owning coal mines and coal mining concessions. $^{10}$

Figure 1: The Map of Location Coal reservation (geological divisions of Energy and Mining Ministry, November 2015)

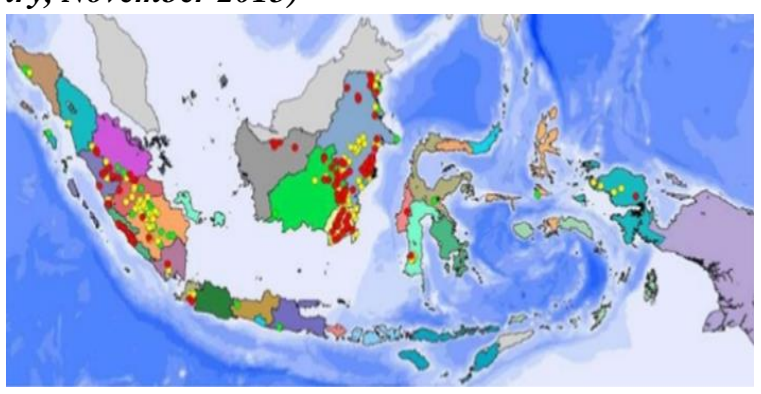

Based on the data from coal and mining ministry (ESDM), the amount of coal resources in Indonesia currently is about 26.2 Billion ton, and its productions is about 461 million ton. Therefore, it can be estimated that now, the coal resources are still 56 years more except we found another new coal resources or new product management. ${ }^{11}$ If it is compared to German and China, they do not use their coal as primary sources of fuel,

9 Lutfi Fatah, 2008, "The Impact of Coal Mining on the Economy and Environment of South Kalimantan Province, Indonesia" ASEAN Economic Policy, 25 (1), pp86-92.

10 (2018) Batu Bara Indonesia. [Online] Available at: https://www.indonesia-investments.com/id/bisnis/komoditas/batu-bara/item236. [retrieved: November 14, 2018]

11 (2018) Cadangan Batubara Indonesia Sebesar 26 Miliar Ton. [Online] Available at: https://www.esdm.go.id/id/media-center/arsip-berita/cadanganbatubara-indonesia-sebesar-26-miliar-ton. [retrieved: November 14, 2018] 
but they find others sources. Especially in Germany, coal is no longer using as fuel for Industry necessary with some considerations last years on 2018. Germany prefer used solar and wind energy. ${ }^{12}$

Based on data from the Directorate of Coal Mining division up to December 2017, there are 3,903 companies obtaining Mining Business License (IUP) consisting of 2,537 Exploration licenses and 1,366 Production Operation license. The data of production, export, domestic usage and price of Indonesian coal from 2007 to 2016 are shown in table 3 .

Table 3: Production, exports, domestic usage and prices of Indonesian Coal 2007-2016 in millions of tons (Directorate of minerals and coal Ministry of Energy and Mineral Resources, 2016).

\begin{tabular}{|lccccccccccc|} 
& 2007 & 2008 & 2009 & 2010 & 2011 & 2012 & 2013 & 2014 & 2015 & 2016 \\
\hline $\begin{array}{l}\text { Produksi } \\
\text { (dalam juta ton) }\end{array}$ & 217 & 240 & 254 & 275 & 353 & 412 & 474 & 458 & 461 & 419 \\
\hline $\begin{array}{l}\text { Ekspor } \\
\text { (dalam juta ton) }\end{array}$ & 163 & 191 & 198 & 210 & 287 & 345 & 402 & 382 & 366 & 333 \\
\hline $\begin{array}{l}\text { Domestik } \\
\text { (dalam juta ton) }\end{array}$ & 61 & 49 & 56 & 65 & 66 & 67 & 72 & 76 & 87 & 86 \\
\hline $\begin{array}{l}\text { Harga (HBA) } \\
\text { (USD/ton) }\end{array}$ & n.a & n.a & 70.7 & 91.7 & 118.4 & 95.5 & 82.9 & 72.6 & 60.1 & 61.8 \\
\hline
\end{tabular}

This should be concern seriously, for the coal reserves in Indonesia as energy and economic support will be exhausted within the next 83 years. The government must reduce the number of Indonesian coal exports and divert domestic compliance therefore coal still can be used for our next generations. In this case, principle of sustainable development should be implemented properly.

The correlation to the Neoliberalism, the state's role in neoliberalism is limited only as a regulator and guardian of market mechanisms. In its development, as pack-

12 Media Center. (2018) Renewable Energy. [Online] Available at: http://www.dw.com/id/energi-terbarukan-dari-bekas-pertambangan/av-18450221. [retrieved: November 14, 2018] aged in the Washington Consensus package, the state's role in neoliberalism is emphasized to do the following four things: (1) implementation of a tight budget policy, including the abolition of subsidies; (2) financial sector liberalization; (3) trade liberalization; and (4) implementation of privatization of SOEs.

Indonesia should return to the Indonesian economic system, people's economic system, as stated in Article 33 of the Constitution, that it is an economic system aimed at realizing people's sovereignty in the economic sector. The four basic principles of people's economy are as follows: 1) The economy shall be organized as a common endeavour based upon the principles of the family system; 2) Sectors of production which are important for the country and affect the life of the people shall be controlled by the state, 3 ) The land, the waters and the natural riches contained therein shall be controlled by the State and exploited to the greatest benefit of the people, 4) The national economy is organised on the basis of economic democracy with the principle of togetherness, fair efficiency, sustainability, environmental in-sight, independence, and by maintaining a balance of progress and national economic unity.

Based on these four principles can be seen how far the role of state in the people's economic system. As provided by Article 27 paragraph 2 and Article 34, the role of the state in the people's economic system includes the following five things: 1 ) develop SOEs; 2) ensure the utilization of the earth, water, and all the wealth contained therein for the greatest prosperity of the people; 3 ) fulfilling the right of every citizen to obtain decent employment and livelihood, and; 4) nurture the poor and neglected children. It is 
a must that the role of law regulates the system of populist economy as stipulated in article 33 of Indonesian constitution

In order to restore the people's economy, one of the important factors is that the leader of the State is not a leader who clearly believes and practices neoliberalism. Greater support as well as criticism and control should be given to leaders who clearly and firmly express their commitment to implement people's economic system in Indonesia.

Indonesia's coal mining legislation, in realizing sustainable development as an effort to improve people's welfare.

Coal is an unrenewable energy resource, therefore the management of utilization of this mineral must be done optimally, efficient, transparent, and sustainable, environmentally concern, and justice, therefore the purpose to utilize maximally and sustainability can be achieved.

The Mining and Coal Law regulates some matters such as the environment including reclamation and post mining, development and empowerment of com-munities around mining areas, settlement of land disputes, development of Indonesian workers, consider the opinions of relevant government agencies, communities, and ecological concern, economic and socio-cultural aspects, as well as environmental perspective; and taking into account regional aspirations, taxes and so forth. (Table 4)

Table 4: Framework of Mining Regulatory governing PNBP, controlling production and environmental obligations

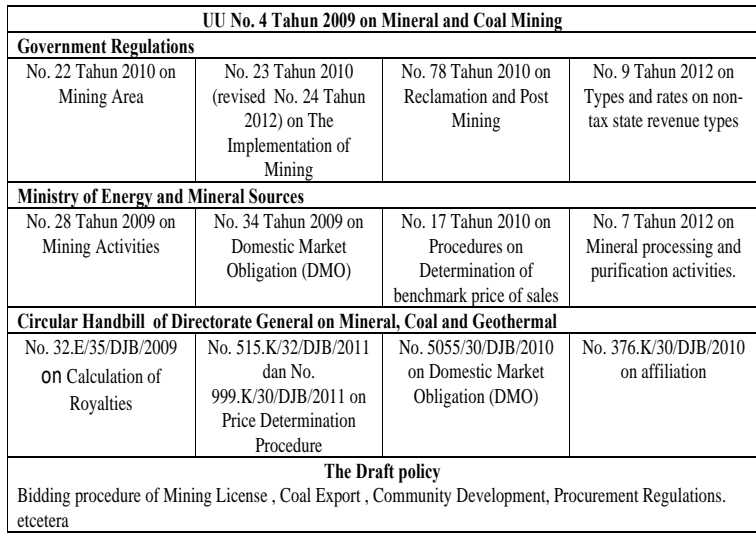

Efforts to prosper the people in coal mining activities are also stated in Indonesian legislation such as Law no. Law No. 40 Year 2007 on Limited Liability Company (UU PT), in Article 74 paragraph (1) states that the Company which conducts its business activities in the field and/or related to natural resources must have the Social and Environmental Responsibility. The mining company's activities are based on the regulations which require mining companies to have Corporate Social Responsibility (CSR) activities, which are budgeted at maximum $4 \%$ of the annual profits especially on stateowned enterprises. ${ }^{13}$ But, the weakness of this regulation is that the private coal mining companies are not binding to this regulation.

Indonesian regulation regarding investment, also stipulate in Article 15 (b): ${ }^{14}$ that to prosper the people every investor is obliged to:

1. Implement good corporate governance principles;

2. Implement corporate social responsibility;

13 The mining company's activities based on the Law on PT, require mining companies to have Corporate Social Responsibility (CSR) activities, which are budgeted at a maximum of $4 \%$ of the annual profits of state-owned enterprises.

14 The 2007 Law No.25 on Investment. 
3. Produce reports on investment activities and submit them to the Investment Coordinating Board;

4. Respect the cultural traditions of the communities around the location of investment business activities; and

5. Respect to all laws and regulations in Indonesia.

Other regulation stipulated on Environmental Protection and Management is the Law No.32 regarding protection and management of the environment which the consideration points $\mathrm{a}, \mathrm{b}$, Article 1 verse 2 and 3 as mentioned below:

1. Considering point a: That a good and healthy environment is the basic right of every Indonesian Citizen as mandated in Article $28 \mathrm{H}$ of the 1945 Constitution of the Republic of Indonesia.

2. Considering point $b$ : Whereas the national economic development as mandated by the 1945 Constitution of the Republic of Indonesia is organized on the principle of sustainable development and environmentally concern.

3. Article 1 verse 2: Environmental protection and management is a systematic and integrated effort undertaken to preserve the environmental functions and prevent pollution and / or environmental damage including planning, utilization, control, maintenance, supervision and law enforcement.

4. Article 1 point 3: Sustainable development is a conscious and planned effort that combines environmental, social, and economic aspects into a development strategy to ensure the integrity of the environment and the safety, abilities, welfare, and quality of present and future generations.

Community participation in coal mining legislation will ensure that the formations of laws will accordance to the values, norms and needs of the people. Thus, the religious values (the One Supreme God), the humanitarian values to guarantee human dignity (just and civilized humanity), the welfare and social justice (social justice for all Indonesians) become important considerations that will used in formation of those regulations.

Some regulations regarding mining as mentioned above still have some weaknesses and various problems, for instant the community in the area is not involved, minimum area for exploration sometimes larger than administrative area of one region, compliance to company obligation to reclamation and post mining, obligation of CSR and others. Therefore, the role of the legal structure is needed in order to enforce the rule of law that accordance to the society values which is Pancasila and Indonesian Constitution.

In the legal factors perspective, one regulation which unenforced is not always because the rule is imperfect, but it's also occur because when the formation of law happens, conditions that will support the implementation is not become the main concern. Nonconductive resources, as well as non-conducive culture will greatly affect to law enforcement. The law will enforce if the role of legal structure is strong. Another important factor to success of law enforcement is not only determined by legal instrument but also the participant of society who concern to the law enforcement itself. ${ }^{15}$

Political law of coal mining in order to realize sustainable development as an effort to improve the welfare of the people according to Indonesia legal system

The legal politics of coal mining in order to realize sustainable development as an effort to improve the welfare of the people accord-

15 Bagir Manan, Konsistensi Pembangunan Nasional dan Penegakan Hukum, Semarang, 1997, p6. 
ing to the Indonesian legal system, emphasizes on 4 (four) principal issues, namely: (1) Legal politics, (2) Coal mining in order to realize sustainable development, (3) improvement of people's welfare (4) Indonesian legal system.

\section{Definition of Political Law}

Legal politics is the process of formation and implementing the system or legal order that governs the life of society in the nation. Starting from the formation of regulation (legal substance), strengthening law enforcement and law enforcement facilities (legal structure) and cultural development

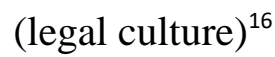

Satjipto Rahardjo said the focus of legal politics study is: ${ }^{17}$

1. What goals are to be achieved within the existing of legal system?

2. What are the best ways to achieve these goals?

3. When the law needs to be changed and how it could be done?

4. Can formulate a pattern and can help us in the process of choosing goals and ways to achieve those goals?

To achieve the legal political study, it is necessary to understand the factors that influence the legal politics of one country:

\section{The level of country's society pro- gress.}

Currently Indonesian is still categorized as traditional community, although some others are category of modern society. Measuring the level of community progress, it is important to observe who will be the subject of the policy and the country. That policy

16 Concluded from Lawrence M. Friedman, American Law, New York: w.w. Norton and Company, 1984, p7, in Rosadi, Otong and Desmon, Andi, Study Politik Hukum (Suatu Optik Ilmu Hukum), Yogyakarta: Thafa Media, 2013, pp4-5.

17 Sathipto, Raharjo, Ilmu Hukum, Bandung: Alumni, 1986, pp309-339. should focus on who the policy is addressing. When addressed to traditional societies, agrarian issues in land tenure and efforts to develop agrarian society using the technology, in order to obtain better and maximum results. If the policy is intended for a modern society, then the issue of employment will consider deeply. Governments should be able to provide jobs with skills or expertise in in facing the industrial need. Therefore, Indonesia should determine the right target policy, and which issues should become the priority. Relation to coal mines, government and mining companies, can applied appropriate pro-grams such as CSR programs for com-munities around the mining area. The community is given land, capital and training if necessary so that they do not lose their livelihood because the land is already used for mining purposes. If the government and mining companies facilitate the interests of the community, certainly the perception and appreciation of the society on the performance of the legal structure and the quality of legal content in this country become positive. This means that even rule of mining law made completely, without support from a good legal structure, it can create a bad legal culture of society. Within the framework of the system, be it the substance of the law, the performance of the legal structure and legal culture must synergize positively.

\section{The order of Community}

The heterogeneous structure of Indonesian society demands legal politics such as unification. The policy should consider the public order and the benefit of that policy to those public. In certain cases, the policy makers should be carefully organising the society in sensitive and personal matters which already exist in people's lives, such as 
religion and people customs. The local government must be careful in granting license to coal mining activities. It should be review carefully, that in giving the license is not damage the composition of the community. Coal mining companies must also respect the diverse communities in the mining business area, such as indigenous peoples.

\section{Political configuration or applicable political system}

In today's democratic society, House of Representatives and the government must be able to accommodate every aspiration in the community. Indonesia's condition with growing issues is human rights violations, poverty, unemployment, environmental degradation, and others. The state is increasingly demanded to establish partner-ship relations with a global civil society which mentioned by Eppler ${ }^{18}$ in term of "third sector" such as the global social movement, civil society networks that address specific issues, international NGOs, etcetera. Civil society is the most original instrument that citizens use to express their aspirations. House of Representative, DPD, as representatives of the people, should think about the people and accommodate all aspirations of the community, especially people in the mining area. Complaints in the mining field should be responded and the aspiration mush be considered. If the House of Representatives and DPD are able to accommodate all of its stakeholder aspirations, then the outcome of political product creates a responsive legal product.

\section{Global development.}

The globalization and the demands of political democratization during the reform period

18 Erhard Eppler, Melindungi Negara Dari Ancaman Neoliberal, Terjemahan Makmur Keliat, Jakarta: Friedrich Ebert Stiftung Kantor Perwakilan Indonesia, 2009, pxii. prompted the government of the reform regime to adopt a policy that is inclined to the spirit of neoliberalism that put forward the role of the market and the owners of capital. But the current condition is influenced by human rights in this case is adjusted to the interests of the Indonesian people.

\section{Coal mining in order to realize sustaina- ble development.}

There are 3 foundations in creating mineral and Coal Law i.e.: philosophical foundation, juridical foundation, and sociological foundation. The philosophical foundation or legal consideration of the establishment coal and mining regulation is, that:

\footnotetext{
"The coal contained in the Indonesian mining jurisdiction is a non-renewable natural resource as a gift of God Almighty who has an important role in fulfilling the livelihood of the people, therefore the management must be controlled by the State to provide real added value to the national economy in an effort to achieve prosperity and the welfare of the people in justice."
}

The existence of coal is a gift of God that must be managed and utilized for the benefit of mankind. The state is authorized to control coal resources. The meaning of the State's tenure is: "The State has full freedom or authority to determine the necessary policy in the form of regulating, managing and supervising the use and utilization of national natural resources". ${ }^{19}$

The Juridical foundation is defined as the legal basis for the implementation of coal mining activities. This foundation is contained in various laws and regulations. Furthermore, the sociological foundation of the establishment of coal mining regulations is due to the people's need for the protection of their rights in the management of coal.

\footnotetext{
${ }^{19}$ Abrar Saleng, Hukum Pertambangan, Yogyakarta: UII Press, 2004, p219.
} 
Because it is stipulated in the Coal and Mining Law, people especially local residents are given enough space to manage coal mining. One of the rights of the community is the right to apply for the Public Mining License (IPR) and the Mining Business License (IUP). By having the license, they can conduct mining activities correctly and it is hope that the community becomes prosperous. But in reality, the activities undertaken by local residents get less attention from the local government because many citizens who conduct illegal mining activities without conducting guidance and supervision. If this is allowed, it will cause considerable problems and losses, both for the environment and community including local government itself.

The Coal and Mining Law provides equal attention to the increase of production and the conservation of the coal resources together with their environment. On the orientation of increased production, it is an attempt to produce as much coal as possible. The cues for this increase in production can be seen from several aspects, namely: First, the placement of coal as one of the components in economic growth. This is stated in the "Considering" which become the philosophical basis. The section B of considering is also mentioned that "Coal is a resource to contribute to national economic growth and sustainable regional development". Second, the implementation of coal mining business activities must be run on the principle of efficient, effective and competitive. Thirdly, the number of products produced should be optimal, which can to contribute to the existing economic growth. Fourth, to support the achievement of such production increase is required to every mining business actor to use good mining technology and large capital.

The orientation of conservation, coal mining is meaningful to the sustainability of the existence of its own coal resources and their utilization. The sustainability of coal resources means that its availability is guaranteed by not exploiting it excessively. Efforts to maintain its sustainability include:

1. The existence of a balance principle, sustainable and environmental insight in the management of coal resources as stipulated in article 2 .

2. One of the objectives of coal management is to ensure that mining benefits are sustainable and environ-mentally insight as referred to in Article 3.

3. Among the criteria used as a reference for determining a mining business area (WUP) is the possibility of the implementation of the conservation code and the guaranteed carrying capacity of the environment as defined in Article 18 and Article 28.

4. The existence of the obligations of business actors related to conservation such as:

- Obligation to undertake post-mining reclamation and monitoring of the environment, including make a planning of reclamation and provide reclamation fund and post-mining guarantee fund as stipulated in article 96.

- The management of mine waste and other material complies with basic standards before they are released into the environment.

- Business actors shall maintain the preservation of the functions and carrying capacity of water resources contained in the WUP.

- Compulsory to suspend of mining activities if the condition of environmental carrying capacity of its business region cannot bear mining activity anymore especially if there 
are reports from the community as stated in Article 113.

In addition to the orientation to increase production and conservation of coal resources and the environment as mentioned in Mining Regulations, coal mining mush also consider to the principles of sustainable development in which every stakeholder should thinking the coal mining holistically for it is involved economic, social and environmental development. ${ }^{20}$ This dimension is carried out with long-term or crossgeneration dimensions, the principle of total efficiency and directed to the reduction of poverty (economy), social equity and higher environmental quality which described in figure 3 .

Figure 3: Interplay of the environmental, economic, and social aspects of sustainable development. Mark Fedkin. Adopted from the University of Michigan Sustainability Assessment, Rodriguez et al., 2002.

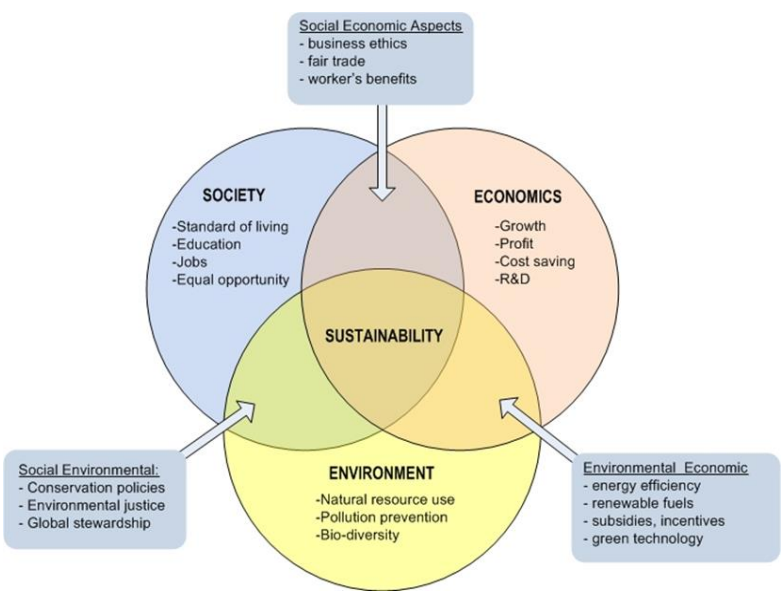

Sustainability is represented as a synergy between society, economy, and environment. Environmental aspects include the use of natural resources, pollution prevention, biodiversity, and ecological health. Social aspects include living standards, the availability of education and employment, and

20 Oekan S Abdoellah, Pembangunan Berkelanjutan Di Indonesia Di Persimpangan Jalan, Jakarta: PT. Gramedia Pustaka Utama, 2016, p74. equal opportunities for all members of the community. ${ }^{21}$ Economic factors are the support for growth, profit, cost reduction, and investment into research and development, and others.

There are more factors that will affect the sustainability of the social system, some of those factors are: social and economic interactions which result the formulation of socio-economic aspect combination such as, business ethics, fair trade, and workers allowance. At the same time, the combination between economic and environment creates an environmental economic which result the improved of energy efficiency, renewable fuel development, green technology, as well as it creates special incentives and subsidies for sustainable environment businesses. The combination of social and environment lead to the creation of conservation policy, the establishment of environmental justice, and global stewardship for sustainable use of natural resources. The figure shows as a simplification framework, which is proves that it can help in identifying key areas of impact and establishing the basis of objective analysis. Further in this process, certain processes and technologies will often be evaluated in terms of social, economic, and environmental impacts, although it must be understood that the three pillars are never completely isolated from each other.

Sutamihardja stated that sustainable development targets include efforts to realize some situation occurs, i.e.: ${ }^{22}$

21 Achmad Romsan, et.al, 2017, "Climate Change and Community Environmental Conflicts, are they correlated?" Sriwijaya Law Review, (1), pp69-73.

22 Sutamihardja, Perubahan Lingkungan Global; Program Studi Pengelolaan Sumber Daya Alam dan Lingkungan Sekolah Pascasarjana; Bogor: IPB, 2004. 
1. Equity of intergeneration equity benefit which means that the utilization of natural resources for the growth needs to consider reasonable limits in ecosystem or environmental systems control and directed to replaceable natural resources and emphasize as low as possible the exploitation of unreplaceable resources nature.

2. Safeguarding or safeguarding the preservation of existing natural resources and the environment that preventing ecosystem disturbances to ensure a good quality of life for future generations.

3. Utilization and management of natural resources for the purpose of pursuing economic growth for the equity of utilization of sustainable natural resources inter generations.

4. Maintaining the welfare of the people (community) that is sustainable both present and future (inter temporal).

5. Maintain the benefits of development or management of natural and environmental resources that have long-term or sustainable long-term benefits.

6. Maintain the quality or quality of human life between generations in accordance with their habitat.

Based on the result of sustainable development measurement, the goals of sustainable development have yet not optimal which is only two third. Its development mostly shown in economic and social sphere, but it is weak for the environment ${ }^{23}$ especially the damages of the environment of coal mining in industry. The Government must have strict regulations to impose the company to do reclamation and post mining. This is because the damage of the environment will affect to indicator of social and economic of society around mining area. For

23 Akhmad Fauzi and Alex Oxtavianus, 2014, "The Measurement of Sustainability Measurement in Indonesia." Mimbar, 30 (1), pp42-52. example, in South Kalimantan, the location of mining is next to the living of people, it's about 20 metres. As the impact of those locations some of citizen house is crack and broken. ${ }^{24}$ According to ministry of Environment regulations stipulated the indicator of coal mining which friendly to the environment must be 500 metres from the border of mining licence area. ${ }^{25}$ Unfortunately, although has been imposed in the regulation, but still there are some violence in mining activities. It means that the enforcement is still weak and need to re-evaluated. ${ }^{26}$

\section{Efforts to improve people's welfare}

The purpose of coal mining as intended in Mineral and Coal Law and the realization of sustainable development is in the framework of improving people's welfare as stipulated in the preamble of the 1945 Constitution and Article 33 (3) and (4) of the 1945 Constitution.

In the preamble of the 1945 Constitution has affirmed the purpose of Republic of Indonesia. There are four purposes: 1) shall protect the whole people of Indonesia and the entire homeland of Indonesia, 2) to advance general prosperity, 3) to develop the nation's intellectual life, and 4) to contribute to the implementation of a world order based on freedom, lasting peace and social justice

24 Coal and Mining Damages. [Online] Available at: http://banjarmasin.tribunnews.com/2018/11/08/C oalandMiningDamages (retrieved: March 28, 2018)

25 Appendix of Ministry of The Environment Regulations of Republic Indonesia Number 04 Year 2012 on The Indicators of Environmental Friendly of Coal Mining Activities in Indonesia.

${ }^{26}$ In some district, it seems that the government pretend not to see some violence. Suparto Wijoyo, 2017, "Tata Kelola Pertambangan dalam Kerangka Indonesia Incorporated untuk Mewujudkan Negara Kesejahteraan." Journal Hukum Lingkungan Indonesia, 4, pp3-7. 
One of the main objectives of the existence of the Republic of Indonesia is to advance people's welfare. Then, to gain that purpose, all the resources in Indonesia should be used and managed optimally. This is stipulated in Article 33 verse (3) and (4) of the 1945 Constitution, which stated that: "The land, the waters and the natural riches contained therein shall be controlled by the State and exploited to the greatest benefit of the people." ${ }^{27}$ And in verse (4) "The organisation of economy shall be conducted on the basis of economic democracy upholding the principles of togetherness, efficiency with justice, continuity, environmental perspective, self-sufficiency, and keeping a balance in the progress and unity of the national economy"

Coal mining contributes to the national economy which should be harmonized in accordance with Article 33 paragraphs (3) and (4) above. But in its implementation, the state is often confronted in a dilemmatic condition between optimal utilization and environmental and social damages, including balancing growth and equity. Currently, it can be seen that there is domination of resources utilization by the state, so it needs new balancing in the form of management of national policy. The national policies referred become the balancing that regulated in a legal system. It seems that the law system in Indonesia is far from fair value. Laws in Indonesia still not consider the living law and culture in society, such as religion value, customary law and public morals, therefore the law applicable is not accordance to the living law in society and feel unfair. On the other hand, the law has not adequately transformed the principles of sustainable de-

\footnotetext{
Article 33 verse 3 of Indonesian Constitution.
}

velopment into the national legal system, therefore it become the barrier in the development process. This is also due to the lack of understanding of the concept of law as a tool of social engineering.

3) Indonesian legal system.

The Indonesian legal system or national legal system is used differently on positive law, but rather conveys Indonesia's constituendum or the legal system that the Indonesian nation aspires to. ${ }^{28}$ What is meant by the national legal system is a legal system that applies with all its elements and support one another in order to anticipate and overcome the problems arising in the life of nation, state and society based on Pancasila and the Constitution of the Republic of Indonesia in $1945 .^{29}$

Accordance to the objective of the development national legal system, there are at least three basic principles as the direction of political legislation, namely:

- The regulations must contain the instruments which support the advance of social welfare and social justice for all of the people of Indonesians.

- The regulations must contain and simultaneously act as instruments in realizing democratic and independent Indonesian society.

- The regulations should contain and simultaneously act as instruments which stipulated that the state is based on the law and the constitution, and also reflects the legal certainty, justice and truth. ${ }^{30}$

28 Sunaryati, Hartono, Politik Hukum Menuju Sistem Hukum Nasional, Bandung: Alumni, 1991, p37.

29 Dajaan Imami and Amiruddin A, Hukum Penataan Ruang Kawasan Pesisir, Harmonisasi Dalam Pembangunan Berkelanjutan, Bandung: Logoz Publishing, 2014, p25.

30 Bagir Manan, Politik Perundang-Undangan, Jakarta: Makalah, 1995, pp18-19. 


\section{CONCLUSION}

Coal as a natural resource within is the unrenewable natural resources, therefore in its management must be done optimally, efficiently, transparently, sustainably and environmentally friendly and equitable in order to advance the maximum benefit for the welfare of the people of Indonesia in a sustainable manner.

Coal mining management must synergise in a legal system. Those are responsive legal substance, the performance of good legal structure and will create a good legal culture as well. Thus, environmentally sustainable development that puts forward economic, environmental and social progress can be balanced to achieve the ultimate goal, the people's welfare.

The existing coal mining regulations considered incomplete currently, therefore, the improvement of regulations and its policy is necessary to achieve the legal objectives in accordance to the values of Pancasila and the 1945 Constitution. The seriousness of law enforcement and the assistance of concerned citizens within the framework of a good legal culture are required in the enforcement of these laws.

The state has an authority to control coal resources. The State's tenure is that "The State has full freedom or authority to determine the necessary policy in the form of regulating, managing and supervising the use and utilization of national natural resources.

\section{REFERENCES}

\section{Books}

Abdullah, S Oekan, 2016. Pembangunan Berkelanjutan Di Indonesia Di Persimpangan Jalan. Jakarta: PT. Gramedia Pustaka Utama.
Baswir, Revrisond. 2009. Bahaya Neoliberalisme. Yogyakarta: Pustaka Pelajar.

Eppler, Erhard. 2009. Melindungi Negara dari Ancaman Neoliberal, terjemahan Makmur Keliat. Jakarta: Friedrich Ebert Stiftung Kantor Perwakilan Indonesia.

Fedkin, Mark. Rodriguez et al., 2002. Adopted from the University of Michigan Sustainability Assessment.

Friedman, Lawrence M. 1984. American Law. New York: w.w. Norton and Company.

Hartono, Sunaryati. 1991. Politik Hukum Menuju Sistem Hukum Nasional. Bandung: Alumni.

Imami, Amiruddin A Dajaan. 2014. Hukum Penataan Ruang Kawasan Pesisir, Harmonisasi Dalam Pembangunan Berkelanjutan. Bandung: Logoz Publishing.

Manan, Bagir. 1995. Politik PerundangUndangan. Jakarta: Makalah.

Manan, Bagir. 1997. Konsistensi Pembangunan Nasional dan Penegakan Hukum. Semarang.

Raharjo, Sathipto. 1986. Ilmu Hukum. Bandung: Alumni.

Rosadi, Otong and Desmon, Andi. 2013. Study Politik Hukum (Suatu Optik Ilmu Hukum). Yogyakarta: Thafa Media.

Saleng, Abrar. 2004. Hukum Pertambangan. Yogyakarta: UII Press.

Sutamihardja, 2004. Perubahan Lingkungan Global; Program Studi Pengelolaan Sumber Daya Alam dan Lingkungan Sekolah Pascasarjana; Bogor: IPB.

\section{Journals}

Fauzi, Akhmad and Oxtavianus, Alex. 2014. "The Measurement of Sustainability Measurement in Indonesia." Mimbar. 30 (1).

Fatah, Lutfi. 2008." The Impact of Coal Mining on the Economy and Environment of South Kalimantan Province, Indonesia." ASEAN Economic Policy. 25 (1). 
Prayogo, Dody. 2008. "Telaah Kritis: Corporate Social Responsibility, Social Justice Dan Distributive Welfare Dalam Industri Tambang Dan Migas di Indonesia." Jurnal Galang. 3 (1).

Romsan, Achmad, et.al. 2017. "Climate Change and Community Environmental Conflicts, are they correlated?" Sriwijaya Law Review. 1 (1).

Wijoyo, Suparto. 2017, “Tata Kelola Pertambangan dalam Kerangka Indonesia Incorporated untuk Mewujudkan Negara Kesejahteraan." Journal Hukum Lingkungan Indonesia. 4 (1).

\section{Laws}

Indonesian Constitution 1945.

The 2007 Law No.25 on Investment. The mining company's activities based on the Law on PT, require mining companies.

Ministry of The Environment Regulations of Republic Indonesia Number 04 Year 2012 on The Indicators of Environmental Friendly of Coal Mining Activities in Indonesia.

\section{World Wide Web}

Coal and Mining Damages. Available at: http://banjarmasin.tribunnews.com/2018/ 11/08/CoalandMiningDamages. [retrieved: March 28, 2018].
Available at :http://kbbi.web.id/makmur [retrieved: March 28, 2018].

Media Center. 2018. Renewable Energy. Available at: http://www.dw.com/id/ener gi-terbarukan-dari-bekas-pertambang-an/av18450221, [retrieved: November 14, 2018].

Mongabay. 2014. Taufik Wijaya dan Rahmadi Rahmad. Batubara, Emas Hitam yang Sarat Permasalahan. Available at: http://www.mongabay.co.id/2014/12 /31/batubara-emas-hitam-yang-sarat-permasalahan/. [retrieved: November 14, 2018].

Cadangan Batubara Indonesia Sebesar 26 Miliar Ton. Available at: https://www.esdm.go.id/id/media-center/arsip-berita/cadangan-batubara-indonesia-sebesar-26-miliarton. [retrieved: November 14, 2018].

Available at: https://www.indonesia-investments.com/id/bisnis/komoditas/batubara/item236. [retrieved: November 14, 2018]. 